\title{
Article \\ Activity of Chloroformic Extract from Salvia connivens (Lamiales: Lamiaceae) and Its Principal Compounds against Spodoptera frugiperda (Lepidoptera: Noctuidae)
}

\author{
Antonio Flores-Macías ${ }^{1}$, Miguel Alejandro Flores-Sánchez ${ }^{2}$, Luis Ricardo León-Herrera ${ }^{3}$, \\ Víctor Manuel Mondragón-Olguín ${ }^{4}$, Carlos Eduardo Zavala-Gómez ${ }^{3}$ 미 , Ana Delia Tapia-Pérez ${ }^{2}$, \\ Juan Campos-Guillén ${ }^{2}$ D , Aldo Amaro-Reyes ${ }^{2}$ D , Diana Issell Sandoval-Cárdenas ${ }^{2}$, \\ Sergio de Jesús Romero-Gómez ${ }^{2}$, Ramón Gerardo Guevara-González ${ }^{3}$, Lourdes Soto-Muñoz ${ }^{4}$, \\ Gerardo A. Zavala ${ }^{5}$ and Miguel Angel Ramos-López ${ }^{2, *(\mathbb{D}}$
}

check for

updates

Citation: Flores-Macías, A.;

Flores-Sánchez, M.A.; León-Herrera,

L.R.; Mondragón-Olguín, V.M.;

Zavala-Gómez, C.E.; Tapia-Pérez,

A.D.; Campos-Guillén, J.;

Amaro-Reyes, A.; Sandoval-Cárdenas,

D.I.; Romero-Gómez, S.d.J.; et al.

Activity of Chloroformic Extract from

Salvia connivens (Lamiales: Lamiaceae) and Its Principal Compounds against Spodoptera frugiperda (Lepidoptera:

Noctuidae). Appl. Sci. 2021, 11, 11813.

https://doi.org/10.3390/

app112411813

Academic Editor: Marcello Iriti

Received: 4 November 2021

Accepted: 9 December 2021

Published: 12 December 2021

Publisher's Note: MDPI stays neutral with regard to jurisdictional claims in published maps and institutional affiliations.

Copyright: (c) 2021 by the authors. Licensee MDPI, Basel, Switzerland. This article is an open access article distributed under the terms and conditions of the Creative Commons Attribution (CC BY) license (https:/ / creativecommons.org/licenses/by/ $4.0 /)$.
1 Departamento de Producción Agrícola y Animal, Universidad Autónoma Metropolitana-Xochimilco, Calz. Del Hueso 1100, Col. Villa Quietud, Mexico City 04960, Mexico; afloresm@correo.xoc.uam.mx

2 Facultad de Química, Universidad Autónoma de Querétaro, Cerro de las Campanas s/n, Col. Las Campanas, Santiago de Querétaro 76010, Mexico; miguel.flores.schz@gmail.com (M.A.F.-S.); deliablue@outlook.com (A.D.T.-P.); juan.campos@uaq.mx (J.C.-G.); aldo.amaro@uaq.edu.mx (A.A.-R.); issell.saldoval@uaq.mx (D.I.S.-C.); serrom@mac.com (S.d.J.R.-G.)

3 Facultad de Ingeniería, Universidad Autónoma de Querétaro, Cerro de las Campanas s/n, Col. Las Campanas, Santiago de Querétaro 76010, Mexico; luis.leon@uaq.mx (L.R.L.-H.); ezavala2@gmail.com (C.E.Z.-G.); ramonggg66@gmail.com (R.G.G.-G.)

4 Agilent Technologies México, Av. Insurgentes Sur 1602, Col, Crédito Constructor, Mexico City 03940, Mexico; victor.mondragon@agilent.com (V.M.M.-O.); musolou@hotmail.com (L.S.-M.)

5 Department of Health Sciences, University of York, Heslington, York YO10 5DD, UK; gzavala@gmail.com

* Correspondence: agromyke@yahoo.com

Abstract: Spodoptera frugiperda (Smith) (Lepidoptera: Noctuidae) is one of the most damaging pests in maize crops. In order to manage it, synthetic insecticides such as diamides, neonicotinoids, and pyrethroids are used, but they present a risk for humans and the environment. Investigations of safer alternatives include the use of natural extracts. Thus, this research evaluated the effects of chloroform extract $\left(\mathrm{CHCl}_{3} \mathrm{Sc}\right)(5000,4000,2000,1000$, and $500 \mathrm{ppm})$ on aerial parts of Salvia connivens and of nonanal and pyrocatechol $(1000,600,400$, and 80 ppm) on S. frugiperda mortality, duration of the larva and pupae phases, and pupae weight after $24 \mathrm{~h}$. The second instars of $S$. frugiperda larvae were fed an artificial diet incorporating the extract and compounds. The $\mathrm{CHCl}_{3} \mathrm{Sc}$ had insecticidal activity against $S$. frugiperda, showing an LC50 of 1504 ppm. Insectistatic activity began at 1000 ppm, increasing pupal and larval duration in 7.6 and 1.4 days, respectively. Pyrocatechol and nonanal were found in this extract. The first did not have any significant difference in larval or pupal mortalities. On the other hand, insectistatic activity was shown at 500 ppm, increasing the larval duration by 1.7 days compared with the control. In the case of nonanal, the insecticide activity was LC50 of $200 \mathrm{ppm}$, and insectistatic activity started at $80 \mathrm{ppm}$, increasing larval duration by 3.2 days compared with the control and reducing pupal weight by $3.4 \%$. The results show that chloroformic extract had insecticidal and insectistatic activities against $S$. frugiperda; nonanal was an aldehyde compound present in this extract, which confers insecticidal and insectistatic activities against this pest.

Keywords: fall armyworm; botanical compounds; nonanal; pyrocatechol; chloroformic extract

\section{Introduction}

Fall armyworm, Spodoptera frugiperda (Lepidoptera: Noctuidae), is a polyphagous insect pest that causes economic losses and affects approximately 80 different crops [1]. This pest is reported in America, Africa, and Asia [2,3]. For the control of this plague, synthetic insecticides, such as chlorantraniliprole, malathion, and imidacloprid (which belong to 
the diamide, organophosphorus, and neonicotinoid chemical groups, respectively [4]), are used but cause environmental damage [5], health hazards, and death [6]. Other concerns related to insecticides include insect resistance and the death of non-target organisms [7]; furthermore, neonicotinoids are related to the reduction in bee populations [8].

One of the alternatives for managing S. frugiperda is the use of plant-based (or botanical) products with insecticidal activity, such as essential oils and organic extracts [9]. The genus Salvia is the most abundant in the Lamiaceae family, reporting approximately 900 species. Salvia plants have been used for medicine, food, cosmetics, and pharmaceuticals [10]. Furthermore, some plant-derived products from Salvia species are studied for their potential use as pest management; examples of this include Salvia hispanica essential oil against Spodoptera exigua (Lepidoptera: Noctuidae) [11]; essential oils from S. dorisiana, S. dolomitica, and S. somalensis against Aedes albopictus (Diptera: Culicidae) larvae [12]; and S. officinalis essential oil against Tribolium castaneum (Coleoptera: Tenebrionidae) adults and Spodoptera littoralis larvae $[13,14]$. S. sclarea aqueous extract has shown insecticidal activity against Trialeurodes vaporiarorum (Hemiptera: Aleyrodidae) adults [15]; a methanolic extract of S. leriifolia mixed with wood vinegar was used against Lasioderma serricorne (Coleoptera: Anobiidae) [16]; and an ethanolic extract of S. sclarea was tested against Culex pipiens (Diptera: Culicidae) larvae [17].

The aim of this study was to evaluate the effect of a chloroformic extract from aerial parts of S. connivens and its major components against $S$. frugiperda.

\section{Materials and Methods}

\subsection{Plant Material}

Aerial parts (leaves and stems) of S. connivens (Figure 1) were collected from the locality Guadalcázar, San Luis Potosí, México (22 $\left.39^{\prime} 50.3^{\prime \prime} \mathrm{N}, 100^{\circ} 24^{\prime} 59.5^{\prime \prime} \mathrm{W}\right)$. Authentication was made by José García-Pérez at the Isidro Palacios Herbarium of the San Luis Potosí Autonomous University (Voucher SLPM 43013).

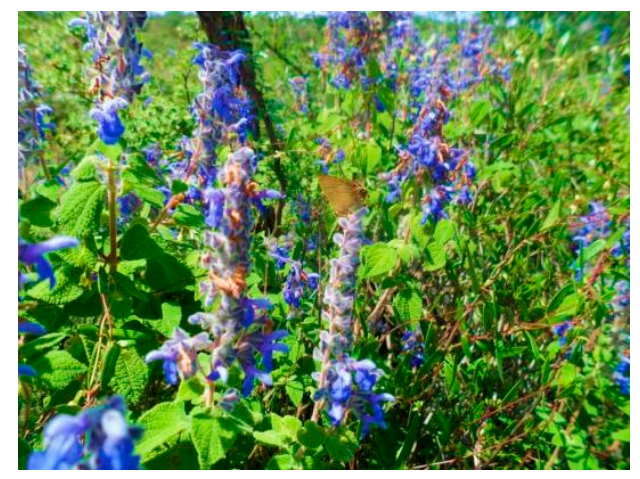

Figure 1. Salvia connivens.

\subsection{Preparation of Extracts of Salvia connivens}

Dried and powdered aerial parts (200 g leaves and stems) from S. connivens were extracted with $1 \mathrm{~L}$ of technical grade chloroform (Meyer, Tlahuac, México City, México) under reflux for $4 \mathrm{~h}$. The extract was filtered, and the solvent was removed under reduced pressure using an RV10 basic rotatory evaporator (IKA, Wilmington, NC, USA). The yield of the extract was $5.13 \%$ [18].

\subsection{Insect Rearing}

Larvae of S. frugiperda were reared at the Insecticidal Natural Compounds Laboratory of the Autonomous University of Queretaro, State of Queretaro, México. The insects were divided into two groups. The control group was fed an artificial diet according to [19]. Briefly, the diet was prepared by incorporating $90 \mathrm{~g}$ of maize grains, $30 \mathrm{~g}$ of bean grains, $0.6 \mathrm{~g}$ of neomycin sulfate, $1.7 \mathrm{~g}$ of sorbic acid (Meyer, Tlahuac, México City, México), $1.7 \mathrm{~g}$ of 
methyl p-hydroxybenzoate (Sigma-Aldrich, Toluca, State of México, México), $10 \mathrm{~g}$ of agar (Meyer, Tlahuac, México City, México), $2.5 \mathrm{~mL}$ of formaldehyde (Meyer, Tlahuac, México City, México), $17 \mathrm{~mL}$ of ethanol (Meyer, Tlahuac, México City, México), $20 \mathrm{~g}$ of brewer's yeast (Meyer, Tlahuac, México City, México), and $800 \mathrm{~mL}$ of distilled water (Ecopura, Queretaro, México). The experimental groups were fed the control group diet mixed with different concentrations of chloroformic extract from the aerial parts of S. connivens, polyvinylpyrrolidone (Sigma-Aldrich, Toluca, State of México, México), and distilled water. The extract was added to the diet when the temperature was $40^{\circ} \mathrm{C}$. The diet was replaced weekly until the pupal stage. Larvae were maintained in a climatic chamber at $27 \pm 2{ }^{\circ} \mathrm{C}$, $70 \pm 5 \%$ relative humidity $(\mathrm{RH})$, and a $14: 10 \mathrm{~h}$ light-dark photoperiod.

\subsection{Bioassays of $\mathrm{CHCl}_{3} \mathrm{Sc}$ on Spodoptera frugiperda}

Preliminary evaluation of $\mathrm{CHCl}_{3} \mathrm{Sc}$ was carried out at five different logarithmic concentrations (ranging from 0.5 to $5000 \mathrm{ppm}$ ) and a negative control (diet only). Test extracts were mixed with the diet and evaluated in groups of $20 \mathrm{~L} 2$ larvae of $S$. frugiperda. Based on the results, the concentration-dependent insecticidal and insectistatic activities were measured. For the final bioassay, the concentrations evaluated were 5000, 4000, 2000, 1000, 500 , and 0 ppm [20].

One larva of the second instar of $S$. frugiperda was deposited in a $25 \mathrm{~mL}$ disposable plastic container with a lid (Envases Primo Cuevas, Ecatepec de Morelos, State of México, México) and fed $3 \mathrm{~g}$ of the artificial diet. Pupae were weighed $24 \mathrm{~h}$ after formation and then left until the adults emerged. The following parameters were assessed: larval mortality, pupal mortality, larval duration, pupal duration, and weight of pupae at $24 \mathrm{~h} \mathrm{[21].}$

\subsection{Determination of the Major Compounds of $\mathrm{CHCl}_{3} \mathrm{Sc}$}

Silica-gel (60) column chromatography (Sigma-Aldrich, Toluca, State of México, México) was used to separate the $\mathrm{CHCl}_{3} \mathrm{Sc}$. Hexane (Avantor, PA, USA) was used as the stationary phase, and ethyl acetate was used as the mobile phase. In order to increase polarity, the ethyl acetate (Sigma-Aldrich, Toluca, State of México, México) ratio was changed from $5 \%$ to $50 \%$. The fractions were analyzed in thin layer chromatography; similar fractions were mixed. The resulting precipitate was filtered in a Buchner funnel followed by hexane (Sigma-Aldrich, St. Louis, MO, USA) rinsing and clarification with activated carbon (Meyer, Tlahuac, México City, México). Furthermore, the sample was analyzed at the Excellent Analytical Measurement Center in México, part of the Agilent Technologies corporation. The analysis was conducted in an Agilent Infinity 1290 liquid chromatography system coupled with Agilent Q-TOF 6530 high-resolution mass spectrometry (Santa Clara, CA, USA). The conditions of the Agilent Zorbax RRHD $(2.1 \times 50 \mathrm{~mm}$, $1.8 \mu \mathrm{m}$ ) silica column were $30^{\circ} \mathrm{C}, 0.4 \mathrm{~mL} \mathrm{~min}^{-1}$ flow rate, and $15 \mu \mathrm{L}$ injection volume. For the mobile phase, the elution gradients were $90 \%$ water (Ecopura, Queretaro, México) and 10\% acetonitrile (Sigma-Aldrich, Toluca, State of México, México) for $10 \mathrm{~min}$, then $5 \%$ water and $95 \%$ acetonitrile for $12 \mathrm{~min}$, and 5\% water and 95\% acetonitrile for $15 \mathrm{~min}$. In all cases, $1 \%$ formic acid (Sigma-Aldrich, Toluca, State of México, México) was added to the water and acetonitrile.

For mass spectrometry (Q-TOF 6530), positive polarity electrospray ionization with a high voltage power supply (ESI) was used. Other equipment parameters were gas temperature, $300{ }^{\circ} \mathrm{C}$; drying gas flow rate, $7 \mathrm{~L} \mathrm{~min}^{-1}$; nebulizing-gas pressure, $40 \mathrm{psi}$; jet stream gas flow rate, $11 \mathrm{~L} \mathrm{~min}^{-1}$; temperature, $325^{\circ} \mathrm{C}$; capillary voltage, $3500 \mathrm{~V}$; and fragmentor voltage, $175 \mathrm{~V}$. A mass analyzer (Q-TOF) was used at a mass-to-charge ratio of $30-700 \mathrm{~m} \mathrm{z}^{-1}$ and an acquisition rate of 1 spectra per second. Component identification was conducted with "Mass Hunter" qualitative analysis software and "Metlin metabolite" accurate mass spectral library [22]. 


\subsection{Bioassay of $\mathrm{CHCl}_{3} \mathrm{Sc}$ Major Compounds on Spodoptera frugiperda}

Preliminarily, five logarithmic concentrations were evaluated $(1000,100,10,1$, and $0.1 \mathrm{ppm}$ ), along with a negative control (diet only), to estimate the biological activity of the major compounds from $\mathrm{CHCl}_{3} \mathrm{Sc}$, taking as reference the highest activity and the first response without activity. Nonanal and pyrocatechol were the main compounds, and different concentrations of each $(1000,600,400,120$, and $80 \mathrm{ppm})$ were mixed with the artificial diet [21,22], as well as food-grade polyvinylpyrrolidone (PVP) (Sigma-Aldrich, Toluca, State of México, México) in a 2:1 weight/volume ratio (PVP:main compound) to obtain an emulsion.

The diet was mixed with each concentration, and a $3 \mathrm{~g}$ cube was deposited inside a $25 \mathrm{~mL}$ disposable plastic container with a lid containing one L2 larva. Five larvae were used as the experimental unit for each treatment, with four repetitions. The conditions and measured variables were the same as previously described.

\subsection{Statistical Analysis}

Data were tested for homoscedasticity and normality. The non-parametric KruskalWallis analysis of variance (ANOVA) and means comparison (Steel-Dwass) tests were used when normality could not be corrected using transformations. Larvae, pupae, and adult mortality were transformed to Bliss degrees. Analysis of variance and Tukey test $(p=0.05)$ were used to determine differences between the control and the treatments. Lethal concentration fifty $\left(\mathrm{LC}_{50}\right)$ was calculated for each treatment by Probit analysis. Data analyses were conducted using SYSTAT 9 software (SPSS Inc., Chicago, IL, USA) [23].

\section{Results}

\subsection{Effect of S. connivens Extract on S. frugiperda}

Larval mortality followed a dose-response curve $(p<0.0001)$, with a mortality of 55 , 70,80 , and $90 \%$ at 1000, 2000, 4000, and $5000 \mathrm{ppm}$, respectively, and $\mathrm{LC}_{50}$ was $1504.03 \mathrm{ppm}$. There was a positive correlation $(p<0.05)$ between the larval mortality and the increase in the concentration of $\mathrm{CHCl}_{3} \mathrm{Sc}$. There were differences between treatments in pupal mortality (Table 1$)$. There was a statistically significantly $(p<0.01)$ longer larval duration at $7.6,9.5,28.2$, and 34.7 days at concentrations of 1000, 2000, 4000, and 5000 ppm, respectively, compared with the control (21.8 days). The period of pupal phase was significantly higher at 1.6 and 4.1 days at 1000 and 2000 ppm compared with the control (9.6 days). The results (Table 1) showed a positive correlation between larval $(p<0.05)$ and pupal $(p<0.05)$ phase duration and increased concentrations of $\mathrm{CHCl}_{3} \mathrm{Sc}$. Moreover, pupal weight was negatively correlated $(p<0.05)$ with the concentration of $\mathrm{CHCl}_{3} \mathrm{Sc}$. Decreases in pupal weights by 39,54 , and $57.4 \%$ were observed at $\mathrm{CHCl}_{3} \mathrm{Sc}$ concentrations of 2000, 4000, and $5000 \mathrm{ppm}$, respectively, compared with the control $(229.8 \mathrm{mg})$.

Table 1. Insecticide and insectistatic activities from chloroform extract of aerial parts of Salvia connivens against Spodoptera frugiperda.

\begin{tabular}{cccccc}
\hline \multirow{2}{*}{ Treatment (ppm) } & \multicolumn{2}{c}{ Mortality $\%$} & \multicolumn{2}{c}{ Duration (days) } & Pupal Weight (mg) \\
\cline { 2 - 6 } & Larvae & Pupae & Larvae & \multicolumn{2}{c}{ Pupae } \\
\hline 5000 & $90 \pm 6.9^{\mathrm{a}}$ & $10 \pm 6.9^{\mathrm{a}}$ & $56.5 \pm 4.5^{\mathrm{a}}$ & $\mathrm{ND}$ & $98 \pm 3^{\mathrm{a}}$ \\
\hline 4000 & $80 \pm 9.2^{\mathrm{a}}$ & $20 \pm 9.2^{\mathrm{a}}$ & $50 \pm 1.2^{\mathrm{a}}$ & $\mathrm{ND}$ & $105.8 \pm 7.7^{\mathrm{a}}$ \\
\hline 2000 & $70 \pm 10.5^{\mathrm{ab}}$ & $15 \pm 8.2^{\mathrm{a}}$ & $31.3 \pm 2.4^{\mathrm{b}}$ & $13.7 \pm 0.3^{\mathrm{a}}$ & $140.2^{\mathrm{a}} \pm 10.8^{\mathrm{b}}$ \\
\hline 1000 & $55 \pm 11.4^{\mathrm{ab}}$ & $15 \pm 8.2^{\mathrm{a}}$ & $29.4 \pm 0.7^{\mathrm{b}}$ & $11 \pm 0.4^{\mathrm{b}}$ & $164.5 \pm 11.9^{\mathrm{bc}}$ \\
\hline 500 & $35 \pm 10.9^{\mathrm{bc}}$ & $0 \pm 0^{\mathrm{a}}$ & $23.7 \pm 1.1^{\mathrm{c}}$ & $9.8 \pm 0.2^{\mathrm{c}}$ & $207.5 \pm 11.2^{\mathrm{bc}}$ \\
\hline 0 & $10 \pm 6.9^{\mathrm{c}}$ & $0 \pm 0^{\mathrm{a}}$ & $21.8 \pm 0.7^{\mathrm{c}}$ & $9.6 \pm 0.2^{\mathrm{c}}$ & $229.8 \pm 4.6^{\mathrm{c}}$ \\
\hline $\mathrm{LC}_{50}$ & & & $1504.03(893.5-2114.6) \mathrm{ppm}$ & & \\
\hline
\end{tabular}

Average values $( \pm \mathrm{SE})$ followed by the same letter are not significantly different $(p<0.05$, Tukey's test). ND, no data because all individuals presented mortality of $100 \%$. 


\subsection{Identification of the Major Components of the Chloroform Extract of Aerial Parts of S. connivens}

Seventeen fractions were separated from the chloroformic extract of $S$. connivens in the thin layer chromatography column. A light-green solid was formed in the 11th and 12th fractions. The liquid fractions were mixed and analyzed. The peak intensities in the chromatogram, mass spectrometry plot, and isotopic profile MFG, showed eight possible compounds (Figure 2, Table 2) at 10.053, 10.168, 11.933, 12.759, 12.760, 12.762, 13.566, and 14.836 min, corresponding to 6E-Octen-2,4-dinoic acid $\left(\mathrm{C}_{8} \mathrm{H}_{6} \mathrm{O}\right)$, S-2-Hidroxyglutarate $\left(\mathrm{C}_{5} \mathrm{H}_{8} \mathrm{O}_{5}\right)$, glutaral $\left(\mathrm{C}_{5} \mathrm{H}_{8} \mathrm{O}_{2}\right)$, 2-octenedioic acid $\left(\mathrm{C}_{8} \mathrm{H}_{12} \mathrm{O}_{4}\right)$, 3-hydroxyphenylglycol $\left(\mathrm{C}_{8} \mathrm{H}_{10} \mathrm{O}_{3}\right)$, pyrocatechol $\left(\mathrm{C}_{6} \mathrm{H}_{6} \mathrm{O}_{2}\right)$ (Figure 3), nonanal $\left(\mathrm{C}_{9} \mathrm{H}_{18} \mathrm{O}\right)$ (Figure 4), and indanone $\left(\mathrm{C}_{9} \mathrm{H}_{8} \mathrm{O}\right)$.

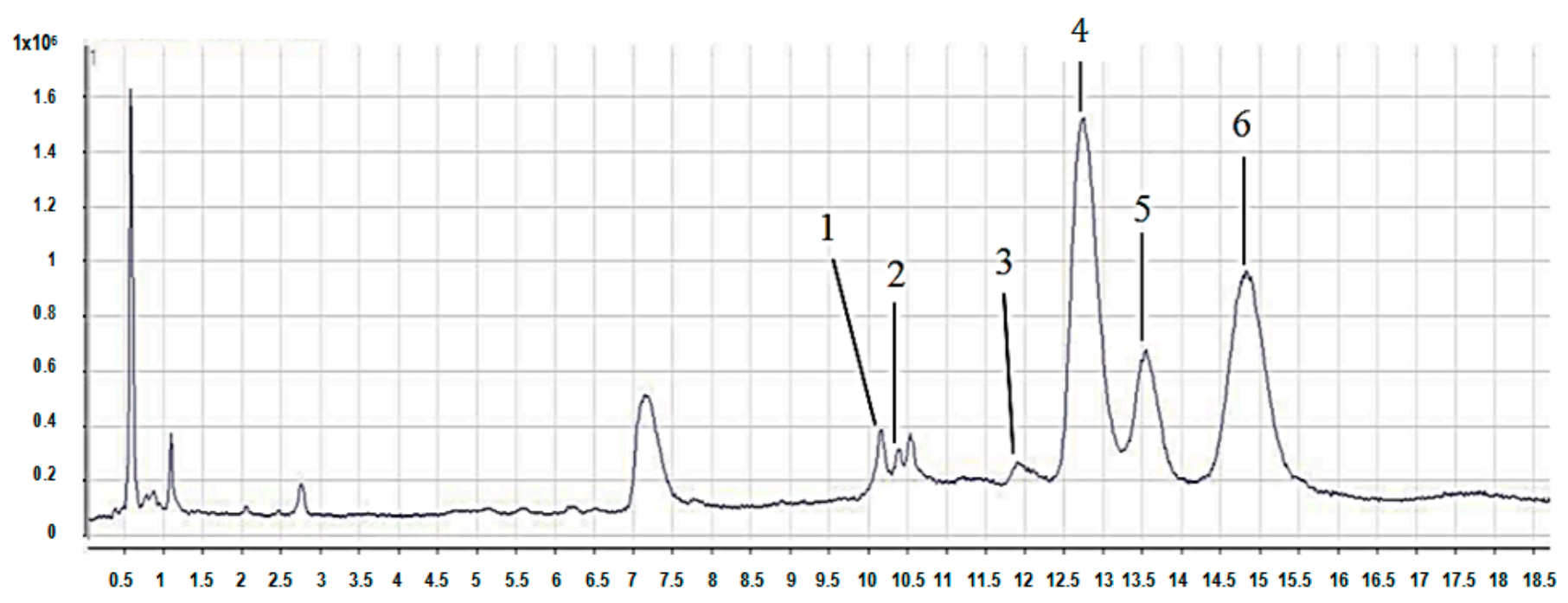

Figure 2. Chromatogram from the 11th and 12th fractions from the chloroformic extract of aerial parts of Salvia connivens. The " $\mathrm{X}$ axis is the area under the curve; the " $\mathrm{Y}$ " axis is retention time.

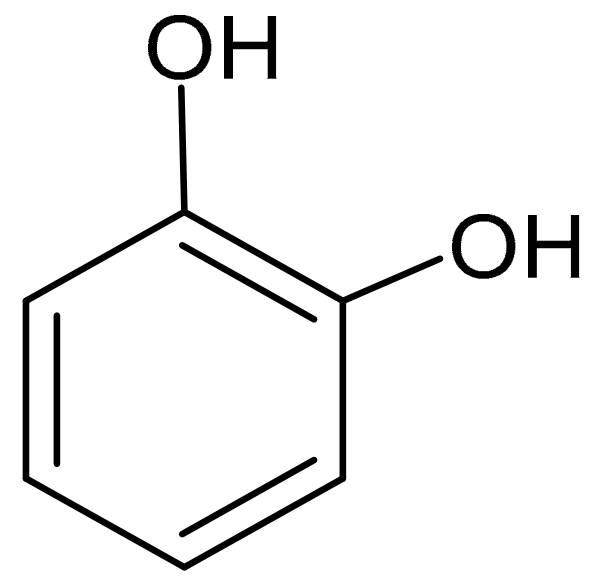

Figure 3. Pyrocatechol.

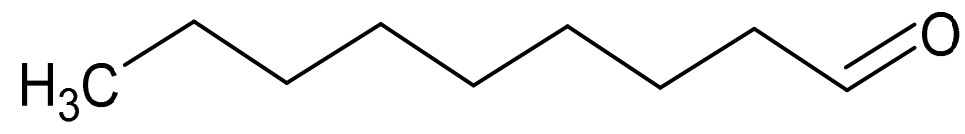

Figure 4. Nonanal. 
Table 2. Main compounds in the 11th and 12th fractions of the chloroformic extract of aerial parts of Salvia connivens.

\begin{tabular}{ccccccccc}
\hline No. & Name & Formula & Mass & Mass (MFG) & RT (min) & DB & MFG & No. of Isomers \\
\hline 1 & 6E-Octen-2,4-dinoic acid & $\mathrm{C}_{8} \mathrm{H}_{6} \mathrm{O}_{2}$ & 134.03 & 134.03 & 10.05 & 97.83 & 97.84 & 6 \\
2 & S-2-Hidroxyglutarate & $\mathrm{C}_{5} \mathrm{H}_{8} \mathrm{O}_{5}$ & 148.03 & 148.03 & 10.16 & 57.70 & 57.72 & 2 \\
3 & Glutaral & $\mathrm{C}_{5} \mathrm{H}_{8} \mathrm{O}_{2}$ & 100.05 & 100.05 & 11.93 & 99.76 & 99.76 & 2 \\
4 & Pyrocatechol & $\mathrm{C}_{6} \mathrm{H}_{6} \mathrm{O}_{2}$ & 110.03 & 110.03 & 12.76 & 95.06 & 95.06 & 4 \\
5 & Nonanal & $\mathrm{C}_{9} \mathrm{H}_{18} \mathrm{O}$ & 142.13 & 142.13 & 13.56 & 96.88 & 96.88 & 1 \\
6 & Indanone & $\mathrm{C}_{9} \mathrm{H}_{8} \mathrm{O}$ & 132.05 & & 14.83 & 90.42 & & \\
\hline
\end{tabular}

RT: retention time; DB: correlation percentage compared with the Metlin database; MFG: correlation percentage compared with the MFG database.

Nonanal was selected because it was the only compound with only one isomer. Pyrocatechol had four isomers; however, it was selected because of its abundance and commercial availability. In contrast, 3-hydroxyphenyl glycol was not selected because it had four isomers and was not commercially available. Indanone, even with a peak in the chromatogram, was not selected because the MFG and number of isomer data were not found, making it difficult to ensure its identification.

\subsection{Biological Response from Pyrocatechol against S. frugiperda}

There was no significant difference $(p<0.05)$ between larval and pupal mortality compared with the control (Table 3). However, there was a significant difference between the treatments and the control in larval duration. The larval duration was 1.7, 2.6, 2.7, 2.6 , and 4.9 days longer at $80,120,400,600$, and $1000 \mathrm{ppm}$, respectively, compared with the control $(p<0.0001)$. The pupal duration was increased by 1.5 and 1.6 days at 600 and $1000 \mathrm{ppm}$, respectively, compared with the control $(p<0.0001)$. Regarding pupal weight, we observed a positive correlation $(p<0.05)$ between the pupae weight and concentration of pyrocatechol; the data show increases of $6.3,6.4,6.6,11.8$, and $14 \%$ at $80,120,400,600$, and $1000 \mathrm{ppm}$ compared with the control $(p<0.0001)$, suggesting that this compound has a fagostimulant activity.

Table 3. Insecticide and insectistatic activity from pyrocatechol against Spodoptera frugiperda.

\begin{tabular}{|c|c|c|c|c|c|}
\hline \multirow{2}{*}{ Treatment (ppm) } & \multicolumn{2}{|c|}{ Mortality \% } & \multicolumn{2}{|c|}{ Duration (days) } & \multirow{2}{*}{ Pupal Weight (mg) } \\
\hline & Larvae & Pupae & Larvae & Pupae & \\
\hline 1000 & $15 \pm 8.2^{\mathrm{a}}$ & $25 \pm 9.9^{\mathrm{a}}$ & $30.2 \pm 0.2^{\mathrm{a}}$ & $15.2 \pm 0.3^{\mathrm{a}}$ & $246.8 \pm 0.7^{\mathrm{a}}$ \\
\hline 600 & $10 \pm 6.9^{a}$ & $20 \pm 9.2^{a}$ & $27.9 \pm 0.5^{b}$ & $15.1 \pm 0.3^{\mathrm{ab}}$ & $242.1 \pm 0.4^{b}$ \\
\hline 400 & $10 \pm 6.9^{a}$ & $20 \pm 9.2^{a}$ & $28.0 \pm 0.5^{b}$ & $14.60 \pm 0.4^{\mathrm{abc}}$ & $230.8 \pm 0.4^{c}$ \\
\hline 120 & $5 \pm 5^{a}$ & $20 \pm 9.2^{a}$ & $27.9 \pm 0.2^{b}$ & $14.1 \pm 0.2^{b c}$ & $230.5 \pm 0.4^{c}$ \\
\hline 80 & $5 \pm 5.00^{a}$ & $15 \pm 8.2^{a}$ & $27 \pm 0.2^{b}$ & $14.1 \pm 0.2^{b c}$ & $230.1 \pm 0.3^{c}$ \\
\hline 0 & $10 \pm 6.9^{a}$ & $10 \pm 6.9^{a}$ & $25.3 \pm 0.3^{c}$ & $13.6 \pm 0.3^{c}$ & $216.5 \pm 0.5^{d}$ \\
\hline $\mathrm{LC}_{50}$ & & & 339.2 (ND) ppr & & \\
\hline
\end{tabular}

Average values ( \pm SE) followed by the same letter are not significantly different $(p<0.05$, Tukey's test).

\subsection{Biological Response from Nonanal against S. frugiperda}

The insecticidal effect of nonanal against $S$. frugiperda began at $80 \mathrm{ppm}$ and was increased significantly $(p<0.0001)$ by $65,70,70$, and y $90 \%$ at $120,400,600$, and $1000 \mathrm{ppm}$ (Table 4); however, pupal mortality was not different between treatments. Regarding insectistatic activity, nonanal increased larval duration in 3.2, 3.9, 5.1, 6.6, and 10.8 days at $80,120,400,600$, and $1000 \mathrm{ppm}$, respectively, compared with the control. However, there were no differences in pupae development. Finally, feeding inhibition was observed with the reduction in pupal weight. A significant negative correlation $(p<0.0001)$ between nonanal concentrations and pupal weight was found with decreases of 3.4, 2.9, 5.8, 8.8, and $24 \%$ at $80,120,400,600$, and $1000 \mathrm{ppm}$, respectively, compared with the control. 
Table 4. Insecticide and insectistatic activities from nonanal against Spodoptera frugiperda.

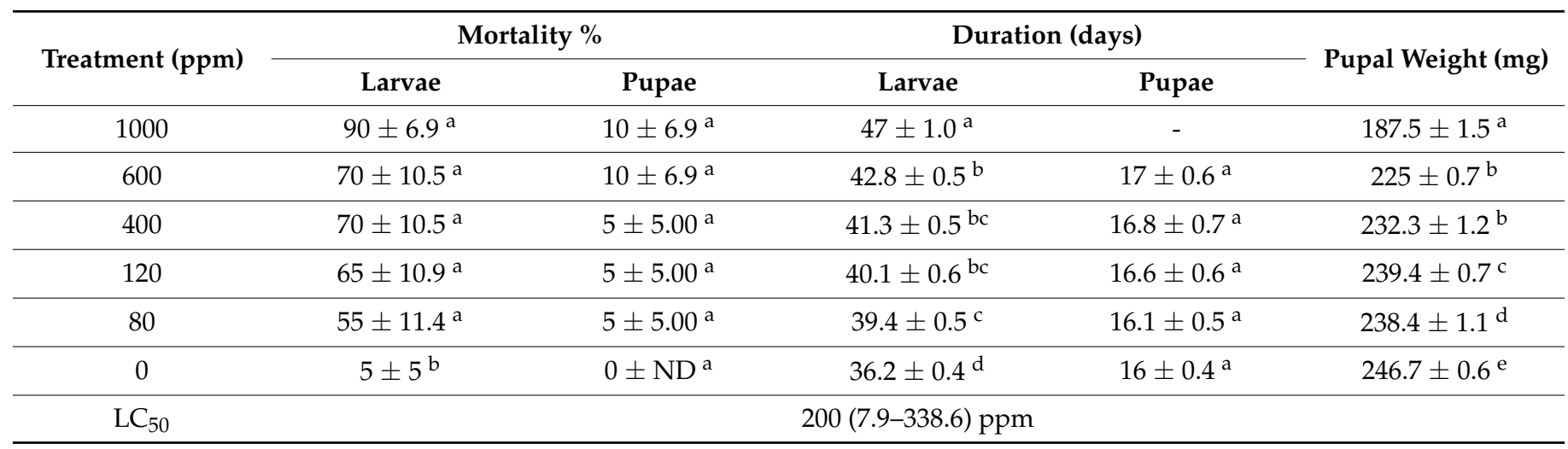

Average values ( \pm SE) followed by the same letter are not significantly different $(p<0.05$, Tukey's test).

\section{Discussion}

Zavala-Sánchez et al. [24] evaluated the insecticidal and insectistatic activities from the chloroformic extracts of the aerial parts of Salvia ballotiflora, S. connivens, S. keerlii, and S. microphilla. They found that S. frugiperda larvae mortality was higher with S. microphilla than with S. connivens, S. keerlii, and S.ballotiflora. With $\mathrm{LC}_{50}$ of 916, 936, 1527 , and $1685 \mathrm{ppm}$, respectively, the pupal mortalities were $83.3,75,62.5$, and $54.2 \%$ with S. microphylla, S. connivens, S. keerlii, and S.ballotiflora. Insectistatic activity began at $500 \mathrm{ppm}$ with all species; larval phase duration increased by 7.6, 6.5, 5.2, and 2.6 days with the S. connivens, S. microphylla, S. ballotiflora, and S. keerlii extracts, respectively. Pupal phase duration increased by 2.3, 2, 1.4, and 1.2 days with S. keerlii, S. microphylla, S. connivens, and S. ballotiflora, respectively. Finally, pupal weight was reduced by $16.4,13.2,12.3$, and $9.8 \%$ with S. keerlii, S. ballotiflora, S. microphylla, and S. connivens, respectively. The $\mathrm{LC}_{50}$ in this work was higher than that reported by previous authors who used the chloroformic extract of the same plant genus, and the insectistatic activity began at $1000 \mathrm{ppm}$ instead of $500 \mathrm{ppm}$. The higher concentration for insectistatic activity found in our study might be related to the fact that the plant material was collected from the same place but during different years, affecting the quality and abundance of secondary metabolites with insectistatic and insecticidal activity [19]. Despite the higher concentration for insectistatic activity, the results suggest that the chloroformic extracts of Salvia connivens have insecticidal and insectistatic activities.

Romo-Asunción et al. [19] evaluated the insecticidal and insectistatic activities of the n-hexane extract of the aerial parts of $S$. microphylla against $S$. frugiperda; the $\mathrm{LC}_{50}$ was $456.2 \mathrm{ppm}$. The larval mortality at $500 \mathrm{ppm}$ was $65 \%$, and pupal mortality was $82.5 \%$. Furthermore, [19] evaluated the insecticidal and insectistatic activities from the chloroformic extracts and found that insectistatic activity began at $500 \mathrm{ppm}$, increasing the larval phase duration by 2 days and the pupal phase duration by 12.1 days, while pupal weight was reduced by $14.1 \%$ compared with the control. Apparently, these species present a higher activity than the present investigation's results, although the different species prevent direct comparisons.

Šućur et al. [15] showed that the aqueous extract from aerial parts of S. sclarea at $1000 \mathrm{ppm}$ in adults from T. vaprariorum had $56.7 \%$ mortality after $120 \mathrm{~h}$. Irfan et al. [25] evaluated the methanolic and aqueous extract of leaves and flowers of S. officinalis against Sitophilus oryzae (Coleoptera: Curculionidae), obtaining 100, 80, and 60\% mortality at concentrations of $15,000,10,000$, and $5000 \mathrm{ppm}$, respectively, with the methanolic extract of leaves; 60,20 , and $40 \%$ at the same concentrations with the methanolic extract from flowers; 60,40 , and $20 \%$ at the same concentrations with the aqueous extract of leaves; and 40,20 , and $0 \%$ at the same concentrations with the flowers aqueous extract. Therefore, there is evidence that aqueous and organic extracts from some Salvia species have insecticidal activity. 
In the case of the composition, Baricevic et al. [26] analyzed the chloroformic extract from leaves of $S$. officinalis, obtaining a chromatographic profile with the most pronounced band corresponding to $48 \%$ of ursolic acid and $1.5 \%$ of carnosol. Alimpić et al. [27] determined the composition from the dichloromethane extract of aerial parts of Salvia amplexicaulis, obtaining hyperoside $(5.4 \%)$, coumarin $(2.9 \%)$, and Genkwanin 5-o-(6'-o-malonyl-glucoside) as major components. Duletić-Laušević et al. [28] found $18.06 \%$ and $7.71 \%$ in the dichloromethane extract from aerial parts of Salvia fruticosa and Salvia lanigera hyperoside, respectively. Furthermore, genkwanin glycosides (1.21\%) appeared in the S. lanigera extract. Some chloroformic and dichloroformic Salvia species extracts contain flavonols, flavones, and polyphenols.

Nonanal has been found to be a constituent of other plants from the Salvia genus, such as the essential oils of Salvia farinacea, S. madrensis, S. splendens, S. leucantha, and S. longispicata, with $6.0,0.8,0.8,0.2$, and $0.1 \%$, respectively [29].

There is evidence that nonanal is present as a metabolite in other species from the Salvia genus. For instance, $0.1 \%$ of the relative concentration percentage of nonanal was detected in Salvia scabra essential oil obtained by hydrodistillation in a Clevenger apparatus [30]. Another example of Salvia taxa with nonanal in the essential oil is Salvia argentea, which contained 0.8\% [31]. Bader et al. [32] analyzed the composition of Salvia samuelssonii essential oil from two different regions of Jordan: As-Subayhi (sample 1) and Al-Adasiyyah (sample 2). These authors reported nonanal as a compound in both essential oils, with $0.6 \%$ in sample 1 and $1 \%$ in sample 2 .

Pyrocatechol has not been reported in other Salvia species. However, pyrocatechol in this species has been reported as pyrocatechol equivalents such as in methanolic extracts obtained by ultrasonic bath of aerial parts from Salvia ringens, S. solaria, and S. nemorosa, which contained 33.19, 26.75, and $21.47 \mathrm{~g}$ of dry weight, respectively [33]. Halfon et al. [34] analyzed the total phenolics in pyrocatechol equivalents from the aqueous, ethanolic, and aqueous extracts from Salvia cassia, obtaining 44.65, 39.87, and $21.34 \mathrm{mg}$ equivalents per $\mathrm{mg}$ of extract.

Pyrocatechol has been reported to have biological activity. Kocacaliskan et al. [35] evaluated the effect of pyrocatechol against plant pathogens that are commonly found in soil. The activity was measured in diameter $(\mathrm{mm})$ of the inhibition zones present on agar medium in Petri plates. In the case of the bacteria Pseudomonas putida, Corynebacterium xerosis, and Pseudomonas pyocyanea, the inhibitions were $31.3,21.6$, and $20.6 \mathrm{~mm}$, respectively, with $0.1 \mathrm{~mL}$ from a $10 \mathrm{mM}$ pyrocatechol solution. In contrast, for the fungi Fusarium oxysporum and Penicillium italicum, the inhibition zones were 29.8 and $26.5 \mathrm{~mm}$, respectively, with the same volume of solution. Ibrahim et al. [36] evaluated the antimicrobial activity of pyrocatechol against Escherichia coli, Salmonella typhi, Pseudomonas aeruginosa, Staphylococcus aureus, and Bacillus cereus, obtaining minimum inhibitory concentrations of $0.67,0.67,1.3$, 1.6 , and $1.8 \mathrm{mg} \mathrm{mL}^{-1}$, respectively. These results suggest that pyrocatechol has antibacterial and antifungal activities, showing that this compound is efficacious against different types of bacteria.

The research results cited above are consistent with the findings of the current investigation, where pyrocatechol had biological but not insecticidal activity against bacteria and fungi. However, it had insectistatic activity, increasing the durations of the larval and pupal periods and probably stimulating the feeding habits.

Other studies of biological effects include Zhang et al. [37], who reported the total inhibition of mycelial growth of Penicillium cyclopium, a phytopathogenic fungi, at $350 \mathrm{ppm}$. Fernando et al. [38] tested nonanal against Sclerotinia sclerotiorum and observed inhibition of the germination of the mycelial plug, suggesting that this molecule has antifungal effects.

Xiu et al. [39] found an attractant effect of nonanal at $10 \mathrm{mg} \mathrm{mL}^{-1}$ in adults of Harmonia axyridis (Coleoptera: Coccinellidae), a predatory insect used as a biological control against Myzus persicae and Aphis gossypii (Hemiptera: Aphididae). Galassi et al. [40] studied the response of Pediculus humanus capitis (Phthiraptera: Pediculidae) to nonanal, finding that it has an attractant effect at $0.001 \mathrm{mg} \mathrm{ml}^{-1}$ but repellency at $10 \mathrm{mg} \mathrm{mL}^{-1}$. Gosset et al. [41] 
found that Solanum tuberosum emitted green leaf volatile compounds, including nonanal, under the attack of Leptinotarsa decemlineata (Coleoptera: Chrysomelidae) as a defense method; however, it acts as an attractant for predators of this insect.

The studies cited above show that nonanal is part of green leaf volatiles in some plant species, acting mainly as an attractant to some insects (mainly predators) and as a repellent against others. However, to the best of our knowledge, this is the first report of nonanal activity against the fall armyworm.

Finally, the results show that $\mathrm{LC}_{50}$ was lower in nonanal (200 ppm), followed by $\mathrm{CHCl}_{3} \mathrm{Sc}$ extract (1504.03 ppm) and pyrocatechol (3339.3 ppm). This could indicate that nonanal has an integral part in the insecticidal and insectistatic effects of $\mathrm{CHCl}_{3} \mathrm{Sc}$ extract against $S$. frugiperda.

\section{Conclusions}

In the present study, the chloroformic extract from aerial parts of Salvia connivens had insecticidal and insectistatic activity against $S$. frugiperda larvae. Pyrocatechol had only insectistatic activity. Moreover, nonanal showed both activities against the $S$. frugiperda insect pest.

The study of plant allelochemicals has been the subject of many studies because of the importance of these substances as an alternative pest management method. In this sense, the potential use of chloroformic extract from aerial parts of S. connivens could be possible if this plant was cultivated because the extract could be standardized with nonanal as a biological marker.

Author Contributions: M.A.R.-L. and A.F.-M., conceived the experiment and wrote part of the manuscript; L.R.L.-H. and M.A.F.-S., performed the investigation and provided methodology; V.M.M.O., L.R.L.-H. and C.E.Z.-G., conducted the experiments; A.D.T.-P. and J.C.-G., elaborated the diet and statistical analysis; A.A.-R. and R.G.G.-G., designed the experiment and collected the data; G.A.Z. and S.d.J.R.-G., reviewed and edited the manuscript; D.I.S.-C. and L.S.-M., performed the statistical analysis and wrote part of the manuscript. All authors have read and agreed to the published version of the manuscript.

Funding: This Scientific Research was supported by the National Science and Technology Council of México (CONACYT).

Institutional Review Board Statement: Not applicable.

Informed Consent Statement: Not applicable.

Data Availability Statement: All data are presented in this article in the form of figures and tables.

Acknowledgments: This scientific research was supported by the National Science and Technology Council of México (CONACYT).

Conflicts of Interest: The authors declare no conflict of interest.

\section{References}

1. Montezano, D.G.; Specht, A.; Sosa-Gómez, D.R.; Roque-Specht, V.F.; Sousa-Silva, J.C.; Paula-Moraes, S.V.; Peterson, J.A.; Hunt, T.E. Host plants of Spodoptera frugiperda (Lepidoptera: Noctuidae) in the Americas. Afr. Entomol. 2018, 26, 286-300. [CrossRef]

2. Goergen, G.; Kumar, P.L.; Sankung, S.B.; Togola, A.; Tamò, M. First report of outbreaks of the fall armyworm Spodoptera frugiperda (J.E. Smith) (Lepidoptera, Noctuidae), a new alien invasive pest in West and Central Africa. PLoS ONE 2016, 11, e0165632. [CrossRef]

3. Lamsal, S.; Sibi, S.; Yadav, S. Fall armyworm in South Asia: Threats and management. Asian J. Adv. Agric. Res. 2020, 13, 21-34. [CrossRef]

4. Sisay, B.; Tefera, T.; Wakgari, M.; Ayalew, G.; Mendesil, E. The efficacy of selected synthetic insecticides and botanicals against fall armyworm, Spodoptera frugiperda, in maize. Insects 2019, 10, 45. [CrossRef] [PubMed]

5. Togola, A.; Meseka, S.; Menkir, A.; Badu-Apraku, B.; Boukar, O.; Tamò, M.; Djouaka, R. Measurement of pesticide residues from chemical control of the invasive Spodoptera frugiperda (Lepidoptera: Noctuidae) in a maize experimental field in mokwa, Nigeria. Int. J. Environ. Res. Public Health 2018, 15, 849. [CrossRef] [PubMed]

6. Mazlan, N.; Ahmed, M.; Muharam, F.M.; Alam, M.A. Status of persistent organic pesticide residues in water and food and their effects on environment and farmers: A comprehensive review in Nigeria. Semin. Ciências Agrárias 2017, 38, 2221-2236. [CrossRef] 
7. Gutiérrez-Moreno, R.; Mota-Sanchez, D.; Blanco, C.A.; Whalon, M.E.; Terán-Santofimio, H.; Rodriguez-Maciel, J.C.; DiFonzo, C. Field-evolved resistance of the fall armyworm (Lepidoptera: Noctuidae) to synthetic insecticides in Puerto Rico and México. J. Econ. Entomol. 2019, 112, 792-802. [CrossRef] [PubMed]

8. Chambers, R.G.; Chatzimichael, K.; Tzouvelekas, V. Sub-lethal concentrations of neonicotinoid insecticides at the field level affect negatively honey yield: Evidence from a 6-year survey of Greek apiaries. PLoS ONE 2019, 14, e0215363. [CrossRef]

9. Hikal, W.M.; Baeshen, R.S.; Said-Al Ahl, H.A.H. Botanical insecticide as simple extractives for pest control. Cogent Biol. 2017, 3, 1404274. [CrossRef]

10. Yadav, A.; Joshi, A.; Kothari, S.L.; Kachhwaha, S.; Purohit, S. Medicinal, nutritional and industrial applications of Salvia species: A revisit. Int. J. Pharm. Sci. 2017, 43, 27-37.

11. Chen, Y.; Luo, J.; Zhang, N.; Yu, W.; Jiang, J.; Dai, G. Insecticidal activities of Salvia hispanica L. essential oil and combinations of their main compounds against the beet armyworm Spodoptera exigua. Ind. Crop. Prod. 2021, 162, 113271. [CrossRef]

12. Najar, B.; Pistelli, L.; Venturi, F.; Ferroni, G.; Giovanelli, S.; Cervelli, C.; Bedini, S.; Conti, B. Salvia spp. Essential oils against the arboviruses vector Aedes albopictus (Diptera: Culicidae): Bioactivity, composition, and sensorial profile-stage 1. Biology (Basel) 2020, 9, 206. [CrossRef] [PubMed]

13. Khedher, M.R.B.; Khedher, S.B.; Chaieb, I.; Tounsi, S.; Hammami, M. Chemical composition and biological activities of Salvia officinalis essential oil from Tunisia. EXCLI J. 2017, 16, 160-173. [PubMed]

14. Khedr, M.M.A. Opportunity for common sage, Salvia officinalis (L) essential oil as a natural biocide against cotton leafworm, Spodoptera littoralis (Boisd.). Pharm. Chem. J. 2019, 6, 47-55.

15. Šućur, J.; Popović, A.; Petrović, M.; Anačkov, G.T.; Malenčić, D.; Prvulović, D. Allelophatic effects and insecticidal activity of Salvia sclarea L. Studia UBB Chem. 2015, 1, 253-264.

16. Hashemi, S.M.; Safavi, S.A.; Estaji, A. Insecticidal activity of wood vinegar mixed with Salvia leriifolia (Benth.) extract against Lasioderma serricorne (F.). Biharean Biol. 2014, 8, 5-11.

17. Cetin, H.; Cinbilgel, I.; Yanikoglu, A.; Gokceoglu, M. Larvicidal activity of some Labiatae (Lamiaceae) plant extracts from Turkey. Phytother. Res. 2006, 20, 1088-1090. [CrossRef] [PubMed]

18. Zavala-Sánchez, M.Á.; Rodríguez-Chávez, J.L.; Figueroa-Brito, R.; Quintana-López, C.M.; Bah, M.M.; Campos-Guillén, J.; Bustos-Martínez, J.A.; Zamora-Avella, D.; Ramos-López, M.A. Bioactivity of 1-octacosanol from Senna crotalarioides (Fabaceae: Caesalpinioideae) to Control Spodoptera frugiperda (Lepidoptera: Noctuidae). Fla. Entomol. 2020, 102, 731. [CrossRef]

19. Romo-Asunción, D.; Ávila-Calderón, M.A.; Ramos-López, M.A.; Barranco-Florido, J.E.; Rodríguez-Navarro, S.; Romero-Gomez, S.; Aldeco-Pérez, E.J.; Pacheco-Aguilar, J.R.; Rico-Rodríguez, M.A. Juvenomimetic and insecticidal activities of Senecio salignus (Asteraceae) and Salvia microphylla (Lamiaceae) on Spodoptera frugiperda (Lepidoptera: Noctuidae). Fla. Entomol. 2016, 99, 345-351. [CrossRef]

20. Rodríguez, C.; Vendramin, J. Toxicidad de extractos de Meliaceae en Sposoptera frugiperda (Lepidoptera: Noctuidae). Man. Integral De Plagas 1996, 42, 14-22.

21. Ramos-López, M.A.; Pérez, S.; Rodríguez-Hernández, G.C.; Guevara-Fefer, P.; Zavala-Sánchez, M.A. Activity of Ricinus communis (Euphorbiaceae) against Spodoptera frugiperda (Lepidoptera: Noctuidae). Afr. J. Biotechnol. 2010, 9, 1359-1365.

22. Yun, L.; Qing, Z.; Dan-Dan, Z.; Fei, C.; Xiu-Hua, K.; Liang, L. Identification and characterization of the major chemical constituents in fructus akebiae by high-performance liquid chromatography coupled with electrospray ionization quadrupole-time-of-flight mass spectrometry. J. Chromatogr. Sci. 2016, 54, 148-157.

23. Ato, M.; López, J.J. Fundamentos de Estadística con SYSTAT; Ra-MA: Madrid, Spain, 1994.

24. Zavala-Sánchez, M.A.; Gutiérrez, S.P.; Romo-Asunción, D.; Cárdenas-Ortega, N.C.; Ramos-López, M.A. Activity of four Salvia species against Spodoptera frugiperda (J.E. Smith) (Lepidoptera: Noctuidae). Southwest Entomol. 2013, 38, 67-73. [CrossRef]

25. Irish, S.R.; Moore, S.J.; Bruce, J.; Birkett, M.A.; Cameron, M.M. Evaluation of a nonanal-trimethylamine lure for collection of Culex quinquefasciatus (Diptera: Culicidae) in gravid traps: Table 1. J. Med. Entomol. 2013, 50, 619-623. [CrossRef]

26. Baricevic, D.; Sosa, S.; Della Loggia, R.; Tubaro, A.; Simonovska, B.; Krasna, A.; Zupancic, A. Topical anti-inflammatory activity of Salvia officinalis L. leaves: The relevance of ursolic acid. J. Ethnopharmacol. 2001, 75, 125-132. [CrossRef]

27. Alimpić, A.; Knežević, A.; Milutinović, M.; Stević, T.; Šavikin, K.; Stajić, M.; Marković, S.; Marin, P.D.; Matevski, V.; Duletić-Laušević, S. Biological activities and chemical composition of Salvia amplexicaulis Lam. extracts. Ind. Crop. Prod. 2017, 105, 1-9. [CrossRef]

28. Duletić-Laušević, S.; Alimpić Aradski, A.; Šavikin, K.; Knežević, A.; Milutinović, M.; Stević, T.; Vukojević, J.; Marković, S.; Marin, P.D. Composition and biological activities of Libyan Salvia fruticosa Mill. and S. lanigera Poir. extracts. S. Afr. J. Bot. 2018, 117, 101-109. [CrossRef]

29. Tabanca, N.; Demirci, B.; Turner, J.L.; Pounders, C.; Demirci, F.; Başer, K.H.C.; Wedge, D.E. Microdistillation and analysis of volatiles from eight ornamental Salvia taxa. Nat. Prod. Commun. 2010, 5, 1421-1426. [CrossRef]

30. Najar, B.; Mecacci, G.; Nardi, V.; Cervelli, C.; Nardoni, S.; Mancianti, F.; Ebani, V.V.; Giannecchini, S.; Pistelli, L. Volatiles and antifungal-antibacterial-antiviral activity of south African Salvia spp. Essential oils cultivated in uniform conditions. Molecules 2021, 26, 2826. [CrossRef] [PubMed]

31. Velickovic, D.T.; Ristic, M.S.; Milosavljevic, N.P.; Davidovic, D.N.; Bogdanovic, S.Z. Chemical composition of the essential oil of Salvia argentea L. Agro Food Ind. Hi Tech 2014, 25, 70-72. 
32. Bader, A.; Cioni, P.L.; De Tommasi, N.; Flamini, G. Essential oil compositions of two populations of Salvia samuelssonii growing in different biogeographical regions of Jordan. Nat. Prod. Commun. 2014, 9, 141-143. [CrossRef] [PubMed]

33. Tusevski, O.; Kostovska, A.; Iloska, A.; Trajkovska, L.; Simic, S. Phenolic production and antioxidant properties of some Macedonian medicinal plants. Open Life Sci. 2014, 9, 888-900. [CrossRef]

34. Halfon, B.; Çetin, Ö.; Kökdil, G.; Topçu, G. Chemical investigation and bioactivity screening of salvia cassia extracts. Rec. Nat. Prod. 2018, 13, 156-166. [CrossRef]

35. Kocaçalişkan, I.; Talan, I.; Terzi, I. Antimicrobial activity of catechol and pyrogallol as allelochemicals. Z. Naturforsch. 2006, 61, 639-642. [CrossRef] [PubMed]

36. Ibrahim, H.A.; Soliman, H.S.M.; Hamed, F.M.; Marrez, D.A.; Othman, S.M. Antibacterial activity of vanillic acid and catechol produced by microbial biotransformation of caffiec acid. J. Pharm. Sci. Res. 2020, 12, 740-743.

37. Zhang, J.-H.; Sun, H.-L.; Chen, S.-Y.; Zeng, L.; Wang, T.-T. Anti-fungal activity, mechanism studies on $\alpha$-Phellandrene and nonanal against Penicillium cyclopium. Bot. Stud. 2017, 58, 13. [CrossRef] [PubMed]

38. Fernando, W.G.D.; Ramarathnam, R.; Krishnamoorthy, A.S.; Savchuk, S.C. Identification and use of potential bacterial organic antifungal volatiles in biocontrol. Soil Biol. Biochem. 2005, 37, 955-964. [CrossRef]

39. Xiu, C.-L.; Xu, B.; Pan, H.-S.; Zhang, W.; Yang, Y.-Z.; Lu, Y.-H. Volatiles from Sophora japonica flowers attract Harmonia axyridis adults (Coleoptera: Coccinellidae). J. Integr. Agric. 2019, 18, 873-883. [CrossRef]

40. Galassi, F.G.; Fronza, G.; Toloza, A.C.; Picollo, M.I.; González-Audino, P. Response of Pediculus humanus capitis (Phthiraptera: Pediculidae) to volatiles of whole and individual components of the human scalp. J. Med. Entomol. 2018, 55, 527-533. [CrossRef]

41. Gosset, V.; Harmel, N.; Göbel, C.; Francis, F.; Haubruge, E.; Wathelet, J.-P.; du Jardin, P.; Feussner, I.; Fauconnier, M.-L. Attacks by a piercing-sucking insect (Myzus persicae Sultzer) or a chewing insect (Leptinotarsa decemlineata Say) on potato plants (Solanum tuberosum L.) induce differential changes in volatile compound release and oxylipin synthesis. J. Exp. Bot. 2009, 60, 1231-1240. [CrossRef] [PubMed] 